\title{
PEREMPUAN, JERAT NARKOBA DAN STRATEGI DAKWAHNYA
}

\author{
Hasyim Hasanah, S.Sos.I, M.S.I
}

Fakultas Dakwah IAIN Walisongo Semarang

\begin{abstract}
Abstrak
Narkoba merupakan problem sosial yang kian hangat diperbincangkan. Berbagai peristiwa ramai menghiasi layar kaca dan menjadi headline news di media massa. Ironinya, perempuanlah yang banyak memainkan peran masuk dalam jerat narkoba, mulai dari kurir, pengedar, pemakai bahkan yang lebih memprihatinkan banyak nyawa perempuan melayang. Diduga kuat, terjeratnya perempuan dalam jerat narkoba dikarenakan faktor psikologis dan ekonomis. Pemenuhan kebutuhan yang semakin kompleks dan kemiskinan yang dialami sebagian besar masyarakat Indonesia khususnya perempuan sebagai pelaku domistik dalam keluarga menjadi salah satu penyebab mereka terjebak dalam jerat narkoba. Iming-iming terbebas dari masalah, mendapatkan kesenangan, penghasilan yang besar menjadi faktor perempuan terjebak dalam jerat narkoba. Bagi sebagian perempuan, masuk dalam jerat narkoba mendatangkan untung yang menjanjikan, namun di balik itu semua, hukuman bahkan ancaman kematian ada di sekitar mereka. Untuk dapat meminimalisir kecenderungan perempuan masuk dan terlibat dalam jerat narkoba, maka diperlukan strategi dawah yang tepat, model dakwah yang dapat menyentuh aspek psikologis dan memberikan landasan pedoman kehidupan yang jelas dan matang.
\end{abstract}

Kata Kunci: perempuan, narkoba, strategi dakwah

\section{A. Pendahuluan}

Tingginya peredaran narkoba dan psikotropika di kalangan perempuan mengakibatkan jumlah pengguna barang haram tersebut meningkat. Berdasarkan data Badan Narkotika Kota (BNK), jika pada 2009 dari 993 pengguna narkoba yang ditangkap 40 orangnya adalah perempuan. 
Hingga pertengahan 2010, dari 400 pengguna narkoba yang ditangkap, jumlah perempuan meningkat menjadi 50 orang. Jumlah itu diperkirakan akan bertambah hingga akhir tahun 2010. dari hasil razia BNK bersama Polrestro Jakarta Pusat selama tahun 2009 dengan jumlah 993 tersangka, 3 di antaranya produsen, 50 persen bandar, sisanya merupakan pengedar merangkap pemakai. Sebanyak 40 pemakai di antaranya perempuan.

Data ini menunjukkan secara perlahan, tetapi pasti banyak kaum perempuan yang terjerat penyalahgunaan narkoba. Penyebabnya diperkirakan mereka diperalat warga negara asing (WNA), penyalahgunaan dan penyebab utama keterlibatan perempuan dengan barang terlarang tersebut diawali ketidaktahuan ${ }^{1}$ ditambah kondisi perekonomian keluarga yang kurang mampu. Terlebih, banyaknya WNA kulit hitam yang bermukim di lingkungan padat dan mengiming-imingi serta menawari berbagai kebutuhan dan akhirnya dijadikan kurir. Sepanjang tahun 2011,dari 44 kelurahan di Jakarta Pusat, 10 kelurahan di antaranya dikategorikan kawasan merah peredaran narkoba meliputi, Tanah Tinggi, Galur, Kampung Rawa, Karang Anyar, Kartini, Kemayoran, Bungur, Petojoutara, Petojo Selatan, dan Duri Pulo. Sementara daerah Kampung Bali dan Kebon Melati, Tanah Abang, yang dulu merupakan zona merah peredaran narkoba saat ini sudah terlepas dari predikat. ${ }^{2}$

Belum lupa dari ingatan kita pemberitaan media massa belakangan ini banyak diramaikan dengan berita kasus narkoba yang melibatkan perempuan. Beberapa kasus narkoba besar yang mengguncang negeri ini mulai dari kasus maut di Tugu Sentani, 9 orang tewas dan 4 luka-luka. Ironinya, maut yang merenggut 9 nyawa tidak berdosa disebabkan karena kelalaian seorang perempuan mengemudikan mobil dalam pengaruh narkoba. Berita tak kalah hebohnya, artis cantik dan bersuara merdu Whitney Huston, ditemukan tewas di bathtub kamar mandi dan diduga

${ }^{1}$ Isep Zaenal Arifin, "Bebas Narkoba Berbasis Lembaga Pendidikan", makalah seminar Menciptakan Lingkungan Sekolah Berbasis Narkoba (LSBN), Universitas Indonesia, Jakarta, 15 April 2000.

2 Hartanto Subijakto, "Perempuan Pengguna Narkoba Meningkat", dalam http://www.kompas.com.html, diakses 6/02/2012 
karena over dosis narkoba yang telah 8 tahun dikonsumsinya. Kejadian ini membuat miris banyak kalangan, khususnya perempuan. Narkoba merupakan persoalan yang bersifat sistemik karena hal ini bisa terjadi di seluruh lini kehidupan yang mengitari siapa saja yang berada di dekatnya. Penyalahgunaan narkoba merupakan perilaku yang dipengaruhi banyak faktor, baik faktor internal maupun faktor yang bersifat eksternal, baik faktor sosial, individual, ekonomi sampai psikologis. Namun demikian pendekatan individual terhadap penyalahgunaan narkoba kurang mendapat perhatian khususnya penyalahgunaan narkoba di kalangan perempuan.

Selain faktor penyebab yang beragam, penyalahgunaan narkoba dapat menimbulkan dampak negatif yang kompleks, meliputi bio-psikososio-spiritual. ${ }^{3}$ Menurut tingkatan efek dari penyalahgunaan narkoba aspek psikis dan spiritual yang memiliki resiko lebih berat karena memiliki rentang waktu yang begitu panjang, khususnya perempuan yang secara psikologis memiliki kecenderungan untuk mengisolasi dan melakukan tindakan di luar batas kemampuan normalnya.

Mendasarkan hal tersebut, maka diperlukan strategi dakwah yang tepat untuk masalah narkoba. Strategi dakwah kendaknya direncanakan sesuai dengan kebutuhan dan dinamika psikologis pelaku narkoba, selain itu, strategi dakwah juga perlu dirancang untuk para keluarga pelaku, hal ini dimaksudkan agar kecenderungan penyalahgunaan narkoba dapat diminimalisir sedini mungkin.

\footnotetext{
${ }^{3}$ Dampak biologis bagi korban narkoba yaitu kerusakan fisik pemakai dengan cirri munculnya berbagai penyakit fisik seperti kerusakan fungsi organ tubuh. Dampak secara psikologis bagi korban (kurir, distributor, pengedar, pemakai, hingga keluarga) adalah beban moral, tekanan mental, perasaan malu dan gagal; kerusakan psikologis atau kejiwaan yang ditandai dengan munculnya penyimpangan perilaku (misbehavior), gangguan psikotik hingga neurotic yang kompleks. Dampak sosial dari penyalahgunaan narkoba adalah tatanan sosial yang porak-poranda, terjadi aliensi sosial dan stigma sosial dengan menanggung rasa malu di tengah masyarakat. Dampak keempat adalah aspek spiritual yaitu hilangnya semangat ketuhanan dalam diri seseorang dan disorientasi kehidupan, sehingga dapat mengakibatkan perilaku yang bahayakan seperti menghilangkan nyawa atau bunuh diri. Lihat dalam Costigan G, The Manual for Reducing Drug-Related Harm in Asia, (Centre for Harm Reduction, 2001), h. 22-30
} 


\section{B. Narkoba}

Kebanyakan zat dalam narkoba sebenarnya digunakan untuk pengobatan dan penelitian. Tetapi karena berbagai alas an, mulai dari keinginan untuk dicoba-coba, ikut trend atau gaya, lambing status sosial, ingin melupakan persoalan dll., maka narkoba kemudian disalahgunakan. Penggunaan terus menerus dan berlanjut akan menyebabkan ketergantungan atau dependensi yang disebut juga dengan kecanduan Tingkatan penyalahgunaan biasanya sebagai berikut: (1) coba-coba; (2) senangsenang; (3) menggunakan pada saat atau keadaan tertentu; (4) penyalahgunaan; (5) ketergantungan. Narkoba adalah zat kimia yang dapat mengubah keadaan psikologi seperti perasaan, pikiran, suasana hati serta perilaku jika masuk ke dalam tubuh manusia baik dengan cara dimakan, diminum, dihirup, suntik, intravena, dan lain sebagainya. ${ }^{4}$ Menurut jenisnya, narkoba dibadi dalam 3 jenis yaitu: Narkotika, Psikotropika, dan Zat adiktif lainnya

\section{Narkotika}

Narkotika adalah zat atau obat yang berasal dari tanaman atau bukan tanaman baik sintetis maupun semi sintetis yang dapat menyebabkan penurunan atau perubahan kesadaran, hilangnya rasa, mengurangi sampai menghilangkan rasa nyeri, dan dapat menimbulkan ketergantungan, atau ketagihan yang sangat berat (Undang-Undang Republik Indonesia Nomor 22 tahun 1997). Jenis narkotika di bagi atas 3 golongan:

a. Narkotika golongan I: adalah narkotika yang paling berbahaya, daya adiktif sangat tinggi menyebabkan ketergantunggan. Tidak dapat digunakan untuk kepentingan apapun, kecuali untuk penelitian atau ilmu pengetahuan. Contoh: ganja, morphine, putauw adalah heroin tidak murni berupa bubuk.

b. Narkotika golongan II: adalah narkotika yang memilki daya adiktif kuat, tetapi bermanfaat untuk pengobatan dan penelitian. Contoh: petidin dan turunannya, benzetidin, betametadol.

4 Rani Putri, “Dinamika Faktor-Faktor Resiliensi Pada Mantan Pecandu Narkoba”, Skripsi, Fakultas Psikologi Universitas Sumatra Utara, 2012, h. 25. 
c. Narkotika golongan III: adalah narkotika yang memiliki daya adiktif ringan, tetapi dapat bermanfaat untuk pengobatan dan penelitian. Contoh: codein dan turunannya (Martono, 2006).

\section{Psikotropika}

Psikotropika adalah zat atau obat, baik alamiah maupun sintetis, bukan narkotika yang berkhasiat psikoaktif melalui pengaruh selektif pada susunan saraf pusat yang menyebabkan perubahan khas pada aktivitas mental dan prilaku, digunakan untuk mengobati gangguan jiwa (UndangUndang Republik Indonesia Nomor 5 tahun 1997). Jenis psikotropika dibagi atas 4 golongan:

a. Golongan I: adalah psikotropika dengan daya adiktif yang sangat kuat untuk menyebabkan ketergantungan, belum diketahui manfaatnya untuk pengobatan, dan sedang diteliti khasiatnya seperti esktasi (menthylendioxy menthaphetamine dalam bentuk tablet atau kapsul), sabu-sabu (berbentuk kristal berisi zat menthaphetamin).

b. Golongan II: adalah psikotropika dengan daya aktif yang kuat untuk menyebabkan Sindroma ketergantungan serta berguna untuk pengobatan dan penelitian. Contoh: ampetamin dan metapetamin.

c. Golongan III: adalah psikotropika dengan daya adiktif yang sedang berguna untuk pengobatan dan penelitian. Contoh: lumubal, fleenitrazepam.

d. Golongan IV: adalah psikotropika dengan daya adiktif ringan berguna untuk pengobatan dan penelitian. Contoh: nitra zepam, diazepam (Martono, 2006).

\section{Zat Adiktif Lainnya}

Zat adiktif lainnya adalah zat-zat selain narkotika dan psikotropika yang dapat menimbulkan ketergantungan pada pemakainya, diantaranya adalah:

a. Rokok 
b. Kelompok alkohol dan minuman lain yang memabukkan dan menimbulkan ketagihan.

c. Thiner dan zat lainnya, seperti lem kayu, penghapus cair dan aseton, cat, bensin yang bila dihirup akan dapat memabukkan (Alifia, 2008).

\section{Perempuan dan Narkoba}

Kriminolog asal Universitas 17 Agustus 1945 (Untag) Surabaya, Kristoforus L Kleden mengatakan dalam teori fiktimologi, bahwa perempuan memiliki potensi lebih dalam segala modus aksi criminal, khususnya penyalahgunaan narkoba. Banyak faktor yang melatar belakangi perilaku penyalahgunaan narkoba. Faktor ekonomi diduga kuat menjadi pemicu keterlibatan perempuan dalam jerat narkoba. Desakan ekonomi yang begitu komplek, khususnya untuk bertahan hidup membuat perempuan kerja keras memutar otak untuk tetap mempertahankan kehidupannya. Perempuan dalam hal ini terlibat dalam jalur perdagangan narkoba, yang secara nyata menjanjikan penghasilan fantastis, tanpa harus melakukan kerja keras seharian penuh. Lagi-lagi kemiskinan memaksa para perempuan untuk masuk dalam jerat narkoba.

Selain faktor ekonomi, kecenderungan keterlibatan perempuan dalam wilayah narkoba adalah aspek sosial, berupa pengakuan status sebagai masyarakat modern dengan hingar bingarnya kehidupan modern. Aspek sosial yang nampaknya menjadi sebab kaum hawa masuk dalam jerat narkoba adalah terkait eksistensi mereka dalam jajaran stratifikasi sosial kelas atas. Faktor selanjutnya yang masih berhubungan dengan dimensi sosial adalah budaya yaitu didasarkan pada masalah konsumerisme. Konsumerisme tampil sebagai gaya hidup perempuan modern. Esposito (2005) menyebutkan bahwa gaya hidup konsumerisme dilakukan sebagai upaya mendapatkan status sosial tinggi diantara kelompoknya. ${ }^{5}$

Faktor selanjutnya adalah pemahaman terhadap agama sebagai falsafah hidup kemanusiaan. Agama yang sejatinya berperan sebagai

\footnotetext{
${ }^{5}$ John Esposito, Islam Aktual, (Jakarta: Inisiasi Press, 2004), h. 42.
} 
benteng dan pondasi dalam menjalani segala aktivitas kemanusiaan nampaknya telah mengalami pergeseran seiring dengan semangat modernitas yang berkembang saat ini. Agama telah kehilangan bentuk dalam upaya menjadikan semangat keadilan, kejujuran, dan menjunjung nilai-nilai keshalehan sosial di masyarakat.

Berdasarkan data Badan Narkotika Kota (BNK), jika pada 2009 dari 993 pengguna narkoba yang ditangkap 40 orangnya adalah perempuan. Hingga pertengahan 2010, dari 400 pengguna narkoba yang ditangkap, jumlah perempuan meningkat menjadi 50 orang. Jumlah itu diperkirakan akan bertambah hingga akhir tahun 2010. Kasubag Refresif BNK Jakarta Pusat yang juga Wakasat Narkoba Polres Jakarta Pusat Ajun Komisaris Santoso menyebutkan, dari hasil razia BNK bersama Polrestro Jakarta Pusat selama tahun 2009 dengan jumlah 993 tersangka, 3 di antaranya produsen, 50 persen bandar, sisanya merupakan pengedar merangkap pemakai. Sebanyak 40 pemakai di antaranya perempuan.

Fakta ini menunjukkan secara perlahan, tetapi pasti banyak kaum perempuan yang terjerat penyalahgunaan narkoba. Menurutnya penyebabnya diperkirakan mereka diperalat warga negara asing (WNA), ungkapnya saat acara peningkatan pemahaman hukum bagi kalangan pelajar SMA dan SMK se-Jakarta Pusat, di Kantor Walikota Jakarta Pusat, Kamis (29/7/2010). Santosa menduga penyalahgunaan dan penyebab utama keterlibatan perempuan dengan barang terlarang tersebut diawali ketidaktahuan ditambah kondisi perekonomian keluarga yang kurang mampu. Terlebih, banyaknya WNA kulit hitam yang bermukim di lingkungan padat dan mengiming-imingi serta menawari berbagai kebutuhan dan akhirnya dijadikan kurir narkoba. ${ }^{6}$

Motif lain terkait dengan penyalahgunaan narkoba (pengedar, kurir, pengguna dan pecandu) secara psikologis terkait dengan aspek identitas diri yang keliru. Identitas diri terkait dengan adanya pengakuan harga diri dari lingkungan sosial yang menurut sebagian besar orang sebagai aku-

${ }^{6} \mathrm{http} / / /$ www.kompas.com./perempuan-pengguna-narkoba-meningkat.html 
mulasi dari dampak negatif narkoba dapat mendongkrak harga diri tinggi sebagai bagian masyarakat modern. Kepuasan diri melahirkan stigma bahwa dengan menjadi bagian dari aktivitas narkoba maka mereka memiliki kepuasan secara pribadi dan sosial, sehingga harga dirinya (self esteem) menjadi tinggi. ${ }^{7}$

Tentu saja perilaku dan penyalahgunaan narkoba bagi perempuan membawa dampak yang luar biasa. Betapa tidak, perempuan selama ini memiliki peran strategis di unit sosial masyarakat (keluarga) membina, mendidik, mengarahkan anak-anaknya menjadi generasi penerus bangsa, yang cerdas dan berakhlakul karimah tentu akan sulit terwujud. Hal ini bida dilihat dari fungsi perempuan ketika menjadi ibu rumah tangga, mereka memiliki tanggung jawab moral terhadap anak-anaknya. Bagaimana penilaian dan dampak psikologi seorang anak jika ibunya masuk dalam jerat narkoba? Inilah yang seharusnya menjadi salah satu pertimbangan kaum perempuan agar memiliki rasa malu untuk penyalahgunaan narkoba. Selain itu, di lingkungan domestik, perempuan juga bisa berperan membentengi keluarga (dirinya, anak, suami dan keluarga) dari penyalahgunaan narkoba dengan menunjukkan empati, kasih sayang, dan pengurusan rumah tangga yang baik, yang tak banyak menuntut kebutuhan pemenuhan materi secara berlebihan. Menyadari sepenuhnya kodrat dan peran sosialnya akan melahirkan efek positif penanggulangan praktik narkoba dikalangan perempuan.

\section{Strategi Dakwah bagi Korban dan Keluarga Koban Narkoba}

Penyalahgunaan Narkoba membawa dampak yang begitu luar biasa khususnya bagi perempuan. Dakwah sebagai salah satu komponen utama ajaran Islam perlu memainkan perannya untuk mengubah tatanan kehidupan masyarakat yang semakin tidak menentu dengan mewujudkan tatanan kehidupan umat Islam yang benar-benar sesuai dengan nilai moral ajarannya, sehingga tatanan kehidupan yang dinamis dan inovatif dapat terwujud, kesejahteraan dan kebahagiaan terealisasikan. Untuk itu diperlu-

\footnotetext{
${ }^{7}$ http://www.detik.com./punk-compulsive-image.html
} 
kan upaya menggiatkan kembali pola dan strategi dakwah yang berorientasi pada keunggulan kaum muslim (khususnya para perempuan) melalui konfigurasi Sumber Daya Alam dan Sumber Daya Manusia secara berkesinambungan.

Strategi dakwah merupakan gabungan dari kata strategi dan dakwah. Strategi sendiri memiliki arti sebagai stratego (dalam bahasa yunani disebut sebagai strato yang berarti tentara dan ego yang berarti pimpinan) seni perang. ${ }^{8}$ Sementara itu dalam persfektif psikologi organisasi strategi merupakan segala perencanaan atas tindakan yang dilakukan untuk mempengaruhi kebijakan, program, perilaku dan praktik public yang meliputi kejelasan tujuan, sasaran dan target, teknik dan kegiatan terkait, dilaksanakan secara sistematis dan terorganisir. ${ }^{9}$

Dalam beberapa literatur disebutkan bahwa tema strategi banyak digunakan dalam praktik pelaksanaan organisasi, baik organisasi sosial, keuangan maupun keagamaan. Menurut fungsinya, strategi merupakan pengejawentahan dari misi suatu organisisi, bermanfaat untuk mengatasi masalah strategis organisasi, menjelaskan respon terhadap kebijakan pokok, merealisasikan sasaran isu organisasi. Startegi dalam pemaknaan konseptual berbeda dengan taktik yang merupakan tindakan atau reaksi jangka pendek, sifat strategi biasanya berorientasi secara luas dan berkedudukan sebagai jembatan yang efektif antara organisasi dengan lingkungan.

Sedangkan dakwah berarti proses islamisasi ajaran Islam, dakwah juga merupakan aktivitas mempengaruhi dan dipengaruhi realitas psikososial yang berkembang, juga dipengaruhi oleh kompleksitas problem kebutuhan dan kejiwaan individu untuk tetap mempertahankan diri dan eksis dalam tataran perkembangan zaman. ${ }^{10}$ Dakwah juga dipahami sebagai proses transformasi dan transmisi nilai Islam dalam realitas

\footnotetext{
${ }^{8}$ Lihat dalam http://www.ebookuliah.com/definisi-strategi-o'toole.html

${ }^{9}$ Sri Hadiati, dkk., Perencanaan SDM: Pendekatan Praktis Perencanaan SDM, (Jakarta: LAN RI, 2005), h. 31

${ }^{10}$ Faizah, dkk, Psikologi Dakwah, (Bandung: Pustaka Setia, 2009), h. 51
} 
kehidupan masyarakat. Berdasarkan konsepsi tersebut, maka strategi dakwah dapat diartikan sebagai suatu perencanaan berbasis kegiatan yang didesain untuk mewujudkan tujuan dakwah.

Sebagai suatu aktivitas perencanaan kegiatan islami, maka dakwah dituntut untuk dapat hadir dengan terobosan baru yang lebih berorientasi pada aspek nilai kemanusiaan, bukan hanya aspek komersial. Strategi dakwah sendiri kini justru mengalami disorientasi konseptual. Hal ini dapat dilihat dari beberapa strategi dakwah yang berkembang dewasa ini secara internal mengalami penurunan kualitas dan terkesan bersifat komersial. Menurut Esposito (2005) bergesernya konseptualisasi orientasi strategi dakwah dikarenakan beberapa faktor diantaranya (1) Melemahnya semangat (ghirah) di kalangan umat Islam; (2) ketakutan melakukan perubahan dan pemaknaan ulang manhaj Islam; (3) bergesernya pondasi perjuangan dakwah Islam yang telah ditetapkan Muhammad SAW dan (4) Ketidaksesuaian strategi yang digunakan dengan kebutuhan umat. ${ }^{11}$

Menurut Azis (2009) strategi dakwah terdiri dari tiga dimensi yaitu: (1) Strategi Tilawah yaitu membacakan ayat-ayat Allah; (2) Strategi Tazkiyah yaitu menyucikan jiwa dari penyakit hati; dan (3) Strategi Ta'lim yaitu mengajarkan dengan hikmah al-hasanah sebagai upaya transformasi pesan dakwah secara mendalam. Sementara itu Aep Kusmawan (2009) menyebutkan bahwa strategi dakwah dapat dilakukan dengan menjabarkan dimensi kerisalahan dakwah (bi ahsan al-qawl). Strategi dakwah melalui dimensi kerisalahan merupakan tuntunan al-Qur'an dengan memerankan tugas kerasulan untuk menyeru manusia lebih mengetahui, memahami, menghayati dan mengamalkan Islam sebagai filosofis (pandangan hidup), sehingga dapat mengarahkan pada perubahan perilaku baik tingkatan individu maupun kelompok kearah yang makin Islami. ${ }^{12}$

Dengan demikian, upaya konseptual strategi dakwah kerisalahan (bi ahsan al-aqwal) mencoba menumbuhkan pemahaman dan kesadaran diri

${ }^{11}$ John Esposito, Islam Aktual: Jawaban atas Gejolak Masyarakat Post-Modern, (terj.), (Jakarta: Inisiasi Press, 2005), h. 34 .

${ }_{12}$ Aep Kusmawan, dalam Aep Kusmawan, dkk., Dimensi Ilmu Dakwah: Tinjauan Dakwah dari Aspek Ontologi, Epistimoloi dan Aksiologi Hingga Pengembangan Profesionalisme, (Bandung: Widya Padjajaran, 2009), h. 16-17. 
individu maupun masyarakat mengenai kebenaran nilai dan pandangan hidup secara islami, sehingga terjadi proses internalisasi nilai Islam sebagai nilai hidupnya. Dakwah kerisalahan dalam praktiknya merupakan proses mengkomunikasikan dan menginternalisasikan nilai islami, artinya Islam menjadi sumber nilai dan dakwah sebagai proses alih nilai, sementara strategi sebagai perencanaan kegiatan dakwah untuk mewujudkan nilai tersebut.

Mendasarkan strategi dakwah pada dimensi kerisalahan, berarti terdapat ruang psikologis yang berperan dalam proses dakwah, yaitu upaya menumbuhkan pemahaman dan sadar diri. Upaya ini menurut pandangan Iqbal (1982) adalah strategi yang mulai banyak ditinggalkan umat Islam. Hal ini dikarenakan mulai ada pergeseran pemahaman bahwa strategi dakwah harus didesain dengan menggunakan media dan sarana-prasarana yang berkembang. Padahal, untuk merencanakan startegi yang tepat seorang harus mengetahui terlebih dahulu kondisi dan kebutuhan sasaran dakwah.

1. Mendasarkan hal tersebut, maka secara umum strategi dakwah yang dapat digunakan untuk menangani masalah ini dapat berupa:

a. Secara internal. Faktor yang sifatnya internal biasanya ditekankan pada tema-tema perkembangan kepribadian. Salah satunya adalah dengan memberikan pemahaman, penghayatan dan pengamalan nilai-nilai ajaran Islam. Dalam konseptualisasi level dakwah Islam adalah mengefektifkan dakwah nafsiah. ${ }^{13}$ Dakwah berbasis diri sendiri. Dakwah nafsiah bertujuan untuk memperbaiki diri sendiri atau membangun kualitas kepribadian diri yang islami. Dalam hal ini seorang dai berfungsi sebagai fasilitator dan mediator bagi para mad'u (perempuan) untuk: (1) memahami hakekat penciptaannya (sebagai makhluk sosial dan makhluk tuhan); (2) memberikan pengertian mengenai potensi dan perkembangan kehidupannya; (3) memberikan penilaian terhadap seluruh sikap dan perilakunya. Dengan beberapa mekanisme ini diharapkan mad'u (para perempu-

${ }^{13}$ Enjang, dkk., Dasar-darsar Ilmu Dakwah, (Bandung: Widya Padjajaran, 2009), h. 64. 
an) mampu menemukan karakter kepribadiannya, sehingga mereka akan menemukan hakekat penciptaannya dan selanjutnya akan senantiasa mengarahkan kehidupannya pada perilaku positif dan menghidarkan diri dari perilaku tercela.

b. Secara eksternal. Setrategi dakwah yang dapat dilakukan melalui faktor yang sifatnya eksternal adalah melalui optimaliasi peran lingkunan sosial. Beberapa tema kegiatan yang dapat dijadikan strategi dakwah adalah pengoptimalan lembaga/institusional dakwah baik melalui kajian keislaman, tabligh, dan aksi sosial. Problematika penyalahgunaan narkoba pada sebagian besar perempuan banyak dilatarbelakangi faktor ekonomi, sebagai upaya pemenuhan kebutuhan agar dapat tetap eksis melanjutkan kehidupannya. Lingkungan yang kondusif dengan diimbangi aktivitas dakwah yang nyata, dirasa dapat memberikan alternatif problem solving bagi pemenuhan kebutuhan umat Islam khususnya para perempuan.

Kajian keislaman menjadi salah satu wadah untuk menanamkan nilai-nilai ajaran Islam secara kontinu. Memanfaatkan keberadaan wadah kelembagan di masyarakat seperti RT, RW dan kelurahan melaui kajian keislaman dapat memberikan kontribusi pemahaman (dampak dan konsekuensi logis penyalahgunaan narkoba) keislaman warga masysrakat khususnya perempuan. Dengan kontinuitas kajian keislaman yang diselenggarakan institusi masyarakat (RT, RW, Forum pengajian dll) dapat memberikan pengetahuan bagi para warga, menumbuhkan solidaritas sosial dalam upaya monitoring dan evaluasi berbagai bentuk penyimpangan yang terjadi di masyarakat.

Tabligh menjadi salah satu strategi dakwah untuk menyiarkan nilainilai ajaran Islam secara komprehensip. Biasanya kegiatan ini bersifat incidental pada even tertentu seperti memanfaatkan momen hari besar keagamaan. Strategi tabligh dapat dilakukan sebagai upaya perjuangan semangat keberislaman, yaitu semangat menyerukan kegiatan amar ma'ruf nahi mungkar yang dapat dilakukan dengan menggali makna historisitas Sirah Nabawiyyah atau Peringatan Hari Besar Islam (PHBI). 
Selain sebagai upaya tablig atau syiar Islam, strategi ini dapat bermanfaat sebagai sarana rekreasi bagi para mad'u. ${ }^{14}$

Strategi ketiga adalah aktivitas sosial. Kebutuhan hidup yang semakin kompleks memaksa para perempuan untuk ikut aktif dalam pemenuhan kebutuhan hidup, dan tak jarang sebaian mereka larut dalam jerat narkoba yang memberikan iming-iming kekayaan instan. Oleh sebab itu dakwah harus memiliki kepekaan terhadap masalah pemenuhan kebutuhan, khususnya pemenuhan kebutuhan pokok bagi umat. Strategi dakwah yang dapat digunakan dalam hal ini adalah dengan kegiatan aksi sosial, khususnya dengan memanfaatkan potensi zakat, infak dan shadaqah. Bentuk nyata pemanfaatan potensi zakat, infaq dan shadaqah adalah penyelenggaraan bakti sosial, pasar murah, santunan orang miskin, anak yatim secara kontinu. Sayangnya pemanfaatan potensi ZIS (Zakat, Infaq dan Shadaqah) belum optimal, sehingga pemenuhan kebutuhan bagi masyarakat kurang mampu belum terpenuhi.

Bagi sebagian besar perempuan, memenuhi kebutuhan hidup adalah harga mati yang tidak dapat tergantikan. Oleh sebab itu para perempuan akan memiliki kecenderungan mengupayakan segala macam cara untuk memenuhinya. Apabila strategi dakwah melalui aksi sosial ini berjalan secara optimal, maka kemungkinan para perempuan melakukan kecenderungan menghalalkan segala cara dalam pemenuhan kebutuhan hidup dapat diminimalisir. Kalau kita dapat melihat, tersistematisasinya para misionaris Kristen dan nasrani, mereka begitu memahami kondisi dan kebutuhan masyarakat, sehingga pola stratehi gerakan "dakwah" yan dilancarkan kaum misionaris sangat tepat sasaran yaitu dengan pembagian paket sembako gratis, uang bahkan biaya pendidikan secara berkesinambungan.

Mendasarkan hal tersebut, maka perlu kiranya bagi kita umat muslim dapat merancang strategi dakwah yang tepat sasaran, khususnya dalam mengentaskan para perempuan lepas dari jerat narkoba, baik melalui

\footnotetext{
${ }^{14}$ Masdar Helmi, “Dakwah Islam: Menggali Format Baru Dakwah Berbasis Sosial Kemasyarakatan", Makalah seminar tentang Strategi Dakwah di Era Globaliasi, Semarang, 2000, h.3.
} 
pemberian paket sembako, pembekalan keterampilan maupun bantuan biaya hidup sehari-hari melalui pengoptimalisasian potensi ZIS.

2. Strategi dakwah bagi penyalahgunaan dan keluarga narkoba.

Menurut Isep (2004) proses dakwah islamiyah jika dilihat dari interaksi antara da'i dan mad'u ada enam konteks yaitu (1) dakwah fardiyah, (2) fardiyah, (3) fi'ah, (4) hizbiyah, (5) ummah dan (6) syu'ubiyah. Bagi korban penyalahgunaan narkoba dapat digunakan model dakwah fardiyah, sedangkan pada keluarga dapat mempergunakan dakwah fi'ah. ${ }^{15}$

Dalam level dakwahnya, strategi yang dapat digunakan bagi keluarga penyalahgunaan narkoba adalah (1) isi materi dakwah didesain berbeda dengan materi dakwh pada umumnya. Karena itu setidaknya bagi seorang $d a ' i$ harus mengetahui pengetahuan mengenai seluk beluk narkoba, psikologis pemakai, psikologis keluarga, pengedar, kurir dan seluruh orang yang terlibat dalam penyalahgunaan narkoba. Materi dakwahnya pun tidak lepas dari hal tersebut, baik pemahamanan narkoba, bahaya dan dampak narkoba, upaya pendampingan, cara mengatasi sampai upaya rehabilitasi mental perlu diketahui. (2) Metode yang digunakan untuk mendekati para korban penyalahgunaan narkoba harus tepat. Salah satunya adalah dengan pendekatan personal dan sosial. pendekatan personal biasanya memiliki tingkat keefektifan lebih tinggi karena dapat secara langsung memahami kondisi mad'u, sehingga alternatif problem solving-nya juga dapat mengena pada kebutuhan mad'u.

Sedangkan dalam bentuk kegiatan dakwahnya, maka dapat dilakukan dengan cara: (1) tabligh Islam diperuntukkan bagi seluruh umat Islam yaitu dengan cara penerangan dan penyebaran pesan Islam; (2) irsyad Islam diperuntukkan baik bagi korban maupun keluarga penyalahgunaan narkoba melalui kegiatan pelayanan bimbingan dan konseling Islam; (3) tadbir menjadi strategi atau bentuk dakwah

15 Isep Zainal Arifin, Pengembangan Dakwah Melalui Psikoterapi Islam, (Jakarta: Rajawali Press, 2004), h. 176-175. 
pemberdayaan umat melalui lembaga dakwah, dan (4) tathwir yaitu upaya pemberdayaan kehidupan melalui pengembangan basis ekonomi. ${ }^{16}$

\section{E. Kesimpulan}

Banyak motif penyebab perempuan masuk dalam jerat narkoba baik sebagai Bandar, pengedar, kurir, pemakai, maupun pecandu narkoba, mulai dari faktor ekonomi, sosial, psikologi, konsumerisme, sapai pada pemaksaan hak-hak perempuan (eksploitasi). Ironis, karena perempuan memiliki stigma besar dalam pembinaan genarasi muda. Apa jadinya bila dalam keluarga, perempuan sebagai figure tauladan anak-anak masuk dalam jerat narkoba. Oleh karena itu perlu ada strategi dakwah yang dirancang sesuai dengan kebutuhan perempuan khususnya para korban dan keluarga penyalahgunaan narkoba. Strategi dakwah secara umum bersifat eksternal dan internal. Eksternal diperoleh dari penyediaan lingkungan sosial yang kondusif, sedangkan secara internal bersumber dari tema-tema perkembangan kepribadian bagi kaum perempuan. Dalam konteks interaksi unsure dakwah strategi yang dapat dilakukan adalah melalui dakwah fardiyah dan dakwah fi'ah, sedangkan dalam level dakwah maka dapat menggunakan strategi irsyat, tablih, tadbir dan tathwir. Seluruh strategi ini didesain dengan model materi dan pendekatan yang disesuaikan dengan kondisi mad'u, apakah perempuan itu sebagai Bandar, pengedar, kurir, pengguna atau pecandu serta keluarga korban penyalahgunaan narkoba.[]

\section{Daftar Pustaka}

Arifin, Isep Zaenal, "Bebas Narkoba Berbasis Lembaga Pendidikan", Makalah seminar Menciptakan Lingkungan Sekolah Berbasis Narkoba (LSBN), Universitas Indonesia, Jakarta, 15 April 2000.

16 Syukriadi Sambas, Dasar-dasar Bimbingan (al-Irsyad) dalam Dakwah Islam, (KP Hadid, 1999), h. 22-23. 
Arifin, Isep Zainal, Pengembangan Dakwah Melalui Psikoterapi Islam, Jakarta: Rajawali Press, 2004.

Enjang, dkk, Dasar-darsar Ilmu Dakwah, Bandung: Widya Padjajaran, 2009.

Esposito, John, Islam Aktual: Jawaban atas Gejolak Masyarakat Post-Modern, (terj.), Jakarta: Inisiasi Press, 2005.

Esposito, John, Islam Aktual, Jakarta: Inisiasi Press, 2004.

Faizah, dkk, Psikologi Dakwah, Bandung: Pustaka Setia, 2009.

G, Costigan, The Manual for Reducing Drug-Related Harm in Asia, Centre for Harm Reduction, 2001.

Hadiati, Sri dkk, Perencanaan SDM: Pendekatan Praktis Perencanaan SDM, Jakarta: LAN RI, 2005.

Helmi, Masdar, "Dakwah Islam: Menggali Format Baru Dakwah Berbasis Sosial Kemasyarakatan", Makalah seminar tentang Strategi Dakwah di Era Globaliasi, Semarang, 2000.

http://www.kompas.com./perempuan-pengguna-narkoba-meningkat.html

http://www.detik.com./punk-compulsive-image.html

http://www.ebookuliah.com/definisi-strategi-o'toole.html

Kusmawan, Aep, dalam Aep Kusmawan, dkk., Dimensi Ilmu dakwah: Tinjauan Dakwah dari Aspek Ontologi, Epistimoloi dan Aksiologi hingga Pengembangan Profesionalisme, Bandung: Widya Padjajaran, 2009.

Putri, Rani, "Dinamika Faktor-faktor Resiliensi pada Mantan Pecandu Narkoba", Skripsi, Fakultas Psikologi Universitas Sumatra Utara, 2012.

Sambas, Syukriadi, Dasar-dasar Bimbingan (al-Irsyad) dalam Dakwah Islam, KP Hadid, 1999.

Subijakto, Hartanto, "Perempuan Pengguna Narkoba Meningkat", dalam http://www.kompas.com.html, diakses 6/02/2012. 